\title{
Adat as a local ideology of indigenous people in political event
}

\author{
Sukri¹, Timo Markus Duile², Ramlah Daud ${ }^{3}$ \\ ${ }^{1}$ Department of Politics, Hasanuddin University, Indonesia. Email: sukripolitik@gmail.com \\ 2 Institute of Southeast Asian Studies, Bonn University, Germany. Email: tduile@uni-bonn.de \\ ${ }^{3}$ Department of Sociology and Anthropology Social, Universiti Sabah Malaysia. \\ Email: mailto:ramlahrd@ums.edu.my
}

\begin{tabular}{l} 
ARTICLE INFO \\
\hline Keywords: \\
Adat; Indigenous People; \\
Ideology; Politic; Toraja \\
Ethnic Group; New Order. \\
How to cite: \\
Sukri., Duile, T.M., Daud, \\
R. (2020). Adat as a local \\
ideology of indigenous \\
people in political event. \\
ETNOSIA: Jurnal \\
Etnografi Indonesia. 5(1): \\
79 - 90. \\
DOI: \\
10.31947/etnosia.v5i1.9705
\end{tabular}

\begin{abstract}
This article aims to show the phenomenon of Adat as an influential factor in Indonesia's regional election process after the New Order Era. The phenomenon seems to indicate a "local ideology" that fundamentally influences people's political behavior within regional elections. Based on the regional election was in the Toraja regions, Province of South Sulawesi in 2015, this article intends to shows how Adat as the Toraja ethnic group foundation of social identity became the fundamental standard of political behavior. It seems to present Adat as an ideology for the ethnic group where dominantly during the regional election. Ultimately, the view from the Toraja regional election has indicated the possibility of local ideology existence where could be crucial for the local political dynamics. It means the ideology as part of political behavior standard is not only present in its general form as known today. Certain communities could have local ideologies based on their local wisdom, and their context was strictly related to efforts to keep their existence as indigenous people as well as their reclaim as the owner of the land.
\end{abstract}

\section{Introduction}

For more than 30 years Indonesia was controlled by the New Order regime until 1998 became the starting point for the regime changes. The regime that was identified as the authoritarian regime ended after the Indonesian multi-dimensional crisis since 1996. The fell of this regime marked by the Suharto's as president of the Republic of Indonesia resigned in the middle of 1998. It then brings Indonesia entering the new era believed as a more democratic era, namely "Era Reformasi" or the Reform Era. Since then, Indonesia has embarked on various changes in socio-political condition, including its political system. It is an intention to leave the authoritarian model of government that has been curbing Indonesian people including the local communities, through strict government control.

One form of control was aimed to the practices of local identities values such as ethnicity 
and Adat which are basically as important aspect of those communities. It was made the local communities values weakened and even lost from its important factors in their region life (see Tyson 2010; Davidson and Henley, 2007). It was happened due to the new order regime saw it potentially become a conflict triggers that should be eliminated. The possibility for conflict is feared to disrupt the regime authorities that possibly emphasizes the political stability were important for their economic development as the main objective policy (Liddle, 1985; Eklöf, 1999).

The concerns regime was actually based on Indonesian objective context as multiethnic country where consisted by hudreds ethnict groups. The number of ethnic groups in Indonesia based on the big ethnic groups, new small ethnic groups, and small ethnic groups is 456 (Ananta et al. 2014). Moreover, based on the BPS census in 2012 categories, Indonesia has 1300 ethnicities, sub-ethnicities, and tribals. The Java ethnic group has the most significant population, around $40 \%$ of the total Indonesian population. Besides the Java ethnic group, there are around 14 ethnic groups that have about 1 million populations (Suryadinata et al. 2003). Since many ethnic groups still have their own local values then Indonesia basically stand at the variety of ethnic group existence. It seen as huge sources for conflict when it does not control well.

That condition made the regime decide to marginalize those communities from the political activities. People become prone to apathy in politics, were made the ruling regime absolutely controlled political dynamics. There was almost no chance for the opposition of people to the state. It seemed to succeed through the cooptation used the uniform ideology called as "Pancasila", where was campaigned as the only ideology for Indonesian people (see Aspinal and Fealy (ed.) 2010). Thru the Pancasila motto "Bhineka Tunggal Ika" or "diverse in unity", the political process was controlled as the only standard for political behaviors in Indonesia.

This political condition seems was stable. But it was only at the surface due to in the local level the conditions actually caused dissatisfaction. The inconvenient was related to fact that many local values are different with Pancasila. It means they were asked to ignore their local values where for generations had been exist as important part of their existence. Although quietly, there were communities still practice their various local values even potentially amid suspicions of the regime and the potentially considered as attitude to ignore Pancasila. It means the New Order regime had never really succeeded to eliminate the local values and its practices in local politics (Sukri, 2018).

When the Suharto regime fell in 1998, one of the phenomena emerged is the rise of public demands for widely participation opportunity in various aspects in their region, including in political activities by prioritizing their local values (Davidson et al. 2010; Tyson, 2010; Nordholt and Klinken, 2007). During the newest era, the government made various changes to the existence of the Indonesian political system. In the local context, one significant change is the regional electoral system to chose the regional head government. Since 2005, the regional electoral mechanism began using the direct election method after previously was done through voting by the regional legislative members only. The change then leaded to a new form of dynamics in Indonesia local politics. 
The regional head position becomes critical and influential in regions due to its authority in regulating his region. It then makes the regional election become an important new competition field of local people. The local people fully pay attention to the regional election process because it will relate to the appropriateness of someone to choose as the most appropriate leader for their context. It means people in the majority should accept the candidate. As a consequence, candidates must have appropriateness based on voter views. In then opened various preferences of people basis assessment and reason to votes. The tendency is seen to occur within the Toraja ethnic group context that also knowing as an indigenous people.

For the Toraja ethnic group, the regional head position is very important, not only in the formal context as the head of the regional government. The position also as significant post in their social and cultural context. A regional head is a reflection of formal governance that leads the land formally and as an important person under the cultural values that should lead this community appropriately based on Adat.

For Toraja people, Adat as well as being understood as a law for this community is based on the sacred values of "aluk to dolo" (the ancestor legacy). It makes the Toraja people always demanded to keep various traditional values in various fields of their lives as an effort to maintain the dynamics of life in their region. It because they deeply respect the ancestors as the aspect of their land blessing. Moreover, it also related to the part of their social identity existence to keep their position as a unique and different ethnic group to others surrounding their regions. Therefore, when the regional election provides an opportunity for people to determine the event result, it cannot be avoided by the phenomenon where Adat.

\section{Method}

This paper is based on the results of research conducted on the community of one of the well-known indigenous communities in South Sulawesi namely Ethnic Toraja. This type of research is qualitative using ethnogprahy methods. Through this method, the research conducted tries to explore how the behavioral tendencies that arise from the Toraja indigenous community when they become determinants in a political event in this case the elections, especially after the new order era.

The fact that they have a fundamental belief in the values of life inherited by their ancestors namely aluk or Adat is an interesting aspect that is the focus of this research. The tendency of the still strong Adat in the daily life of the Toraja ethnic, especially those who live in the Toraja region, has opened up local political space in this region in a situation where local values play an important and very basic role in determining the outcome of the elections.

The data, mainly obtained through in-depth interviews with key informants. In this case the key informants consisted of community leaders, traditional leaders who were chosen based on the snowball sampling method. Interviews were also conducted with the community, especially those who had participated in the regional head election process, where the determination of the information was also based on the random sampling method. Based on various data, the conclusions are drawn based on analysis related to 
the existence of a basic value that becomes the standard of political behavior of the Toraja community that shows its tendency as an ideology.

\section{Result and discussion}

\section{- Importance of Adat for the Toraja Ethnic Group}

The Toraja is a region in the northern part of the South Sulawesi Province, Indonesia. This region was originally as one district, namely the Tana Toraja Regency. However, since 2008, the regency has been divided into two administrative regions, Tana Toraja Regency and the new regency is the North Toraja. Although administratively separated, this regency still has the same trending tendency. Both districts in the Toraja region are inhabited majority by the Toraja ethnic group. The Toraja is one of the major ethnic groups based on the number of its population in the South Sulawesi Province except for the Bugisness, Makassarese, and Mandarness. The population oh this ethnic group is more than 1 million where around hal of them are live in both districts. The number of Toraja ethnic groups in this region is more than $80 \%$ of the total population in each district. The number of the Toraja ethnic group in both districts is close to 500 thousand (The North Toraja Government 2015).

The Toraja ethnic group or the Torajas tends to have significant differences with the other groups. It at least occurring through this community local culture in the name of Adat that is still exists strongly and implemented within this ethnic group differently to others. One of important things to the adat existence is related to it tendency to influencing this community behaviour in their daily lives. It also as the condition why this community also recognizing as an indigenous people.

Basically, in Indonesia, Adat has always been associated with a set of social rules, habits, politics, perceptions of justice, and even individual habits for centuries (Prins 1951 cited in Tyson 2010:1). In addition, Adat is recognizing as something that changes, a unified concept that encompasses various unique customs and traditions of each of the main ethnic groups in Indonesia (Tyson, 2010:1). Adat also re-present a system of government based on oral tradition, antecedents, and customary law, which provides a set of rules for ceremonies for weddings and funerals, houses and harvests, or land use and rights mechanisms (Hooe, 2012: 1). Therefore, Adat is not only seen as a series of ceremonial activities that are present in a series of activities in the community merely shows certain symbols of their social identity. More than that, Adat is a system of trust from a community of people towards certain values that are accepted as a common value, even so that it is one of the important aspects of the basic identity of a particular community. Therefore, the existence of Adat is one of the important indications for the existence of a community with unique values as an indigenous community.

For this ethnic group, their indigeneity is more outward as a combination of myth, origins, legends, and the transfer of memories from the past orally to its present generations. That combination is united in the fundamental values called aluk to dolo or the "ancestor legacy" (Kobong et.al., 1992). Actually, aluk is originated from the Toraja ethnic group's old religion that believes in gods. Aluk is believed as guidelines for the torajas towards the enlightenment as the phrase "anna bendan tutungan bia 'tunannang 
tendanan ma'lana-lana", which means aluk is "the stand flame torches, where in upright position". The torches symbolize as the direction to good and wealthy life. In the Toraja mythology, numbers of torches are 7777777 or in another version amounted of 7777 that implies completeness, where also knowing as "aluk sanda pitunna" (the all seven commands). The aluk believed contains guidelines for all aspect of people life because it was created by the gods where they are also believed to live within the rules (Kobong et.al., 1992). Their obedience believes will bring fortune while a violation potentially brings some misfortune in them. Therefore, the Toraja ethnic group still keeps aluk as within their life. Their existence could not be separated from the aluk or Adat as foundation of their ethnicity identity (Kobong et.al 1992).

In general, fields are supported in "aluk" are; Aluk mellolo (concerning to human birth adulthood); "Aluk Rambu Tuka" concerning to the marriage party; "Aluk Rambu Solo" concerning to the funeral ceremony; "Aluk Bua" concerning to the joy party; "Aluk Tunanan pasa" involving market and activities to fullfil their needs; "Aluk Tedong" Concerning to Buffalo or livestock; "Aluk Pare" Concerning to Rice and Food; "Alukna Bangunan Banua" concerning to the construction of the house; and "Aluk Padang" concerning to land (Kombong et.al 1992:20-21).

The aspects regulated in aluk basically become a series of life guidance that contains various commands and prohibitions (Kombong et al. 1992: 20-21). Therefore, based on the aluk, all aspects should be based on its guidance due to it is considered as a representation of the presence of their ancestors. Actually, many of the Toraja ethnic group are in touch with aspects of modernity such as educational institutions, employment and through contact with religion other than aluk, the majority of Toraja people still keep the local guidelines not only for those who majority live in Toraja regions but also those who liveoutsides (De Jong, 2013).

One of important characteristics of the Toraja ethnic group as an indigenous people that still exists as part of the adat existence is the caste-based communities. The Toraja still distinguishes in four castes, namely Tana 'Bulaan (King descendants / highest nobility), Tana' Bassi (Descendants of middle aristocrats), Tana 'Karurung (ordinary people) and the Tana 'Kua-kua (formerly considered as slaves). Since the Dutch colonial occupied this region hundreds of years ago, the slave had been banned. However, the castes system still exists, and even the slave still could be considered, especially during various adat ceremonies. One of the consequences is the standard that must be met by someone who will become a community leader in the context of the Toraja people, especially in the regions.

Their guidelines teach that a leader is, at the same time, a person who bears great responsibility for the condition and existence of this community. Thus, a leader must be able to prosper the community. Therefore, a leader must have appropriateness in accordance with the conditions set out in adat guidelines. In accordance with customary guidance, a leader must have 4 important things in order to be considered appropriate based on Adat. These four things are "ability or capability", "wisely attitude", possessing "wealthy", and the most important are "nobility" (Sukri, 2018). 
The first three requirements are tended similar to the modern standards of various organizations or business institutions for a leader (see Raišienė, 2014; Gold et.al 2010). The three conditions basically can always be found in various community contexts, but the thing that distinguishes them is the necessity as a descendant of a noble for a leader. This then tends to exclude the opportunity for people to become leaders by limiting it to the elite of the community with a background of nobility. This condition could be seen as an unfair condition for those who are not noble descendants. However, in the context of the Toraja people, this condition is propriate.

This understanding is precisely evoked in the belief that their region and society will get blessings from the almighty if they are led by people who are appropriate because they are considered to have a better view related to how govern this community based on the traditional values. Due to their reclaim the regions as their sacred land, only certain people will get blessings to lead this community under the appropriate adat values. Therefore, a leader of this ethnic group should be in line with the adat requirements (Kobong et.al., 1992: 20). At this point, Adat is more likely to regulate how the Toraja must issue about leaders in their region in the socio-cultural context. However, when the election system is related to the effort to choose a formal government leader in the Toraja region, Adat experiences functional adjustment.

The election is an effort to chose a leader who will regulate the lives of people in the Toraja region based on formal law. But due to this ethnic group is the majority and they claims the regions as their sacred land then regiona election result should appropriate, with the Toraja ethnic group preferences about a leader. The Toraja people are then forced to address the right behavior based on their fundamental belived on Adat could not be avoided from their political behaviours within the election.

\section{- Adat as Local Ideology within The Regional Election}

Related to ideology many experts agree that there is no definite understanding related to ideology. So far, ideology tends to be understood in many meanings. Ideology has a relationship with an idea, belief, understanding, and certain attitudes. Besides, ideology can also be understood as a cognitive assumption that underlies a certain belief or total structure of thought. Ideology also shows the existence of links with certain groups, classes, or collectivities within a wider scope of society. Ideology can also be related to the whole society or community, which places it as the highest value related to the existence of a particular class or group of people. Ideology is also sometimes seen as a standard of behavior that encourages action or encourages an action to take action (Hamilton, 1987). However, ideology seems inseparable from the influence of its existence on individual and group behavior (Szalay and Kelly, 1972).

Therefore, an ideology is a system that is collectively considered normative and may be factual ideas and beliefs and attitudes that support certain patterns of relationships and social arrangements, or can also aim to justify a pattern of behavior, which advocates want to promote, realize, chased or defended. Thus an ideology seems not just a tool for persuasion, control of perception, values, and beliefs, but also a form of self-justification allows us to consider the possibility of a 'dominant' ideology, especially with certain groups or classes of society (Hamilton,1987). 
The fundamental aspects of ideology are related to the basic principles that exist in a class or group of people as a standard value that makes them have the same tendency as culture in society. In this regard, through his observations Hamilton (1987 in Griffin 2006) offers observations in his efforts to define ideologies that are interpreted similarly to the meaning of Culture as "How a person categorizes reality depends on one's goals, questions raised, and often prior dispositions and commitments. to a specific explanation about that".

This seems to indicate how the convergence between similar ideological and cultural terms is mainly related to the non-material aspects of human existence relating to the subjective realm of ideas, values, world views, and cosmology, things that are very important in human history (Griffin, 2006). The interrelation of the two terms is very close to seeing the assumption that 'traditional ideas and attached values' which form the core of cultural thinking also includes action in the context of understanding with ideology which essentially contains an understanding of the existence of actions based on a certain standard of belief. Culture consists of patterns, explicit and implicit, from and for behaviors that are acquired and transmitted by symbols, constituting the distinctive achievements of human groups, including their manifestations in artifacts; the essential essence of culture consists of traditional (eg, ideas that were handed down and chosen historically) and especially the attached values; Cultural systems can, on the one hand, be considered as products of action, on the other hand as conditioning elements of further action (Kroeber and Kluckhohn in (1952) in Griffin 2006).

By following the logic of 'anthropological' universalization, efforts to understand ideology make it possible to see it as a latent 'aspect' of all human cultural activities and their material products.

Phenomenologically human existence is lived and experienced non-ideologically, but when externalized in a semiotic or material culture, it is directly in the ideological dimension when one result is considered from an outsider's perspective regarding their function in maintaining or challenging a status quo condition in social, economic, or political aspects. In this case, at the individual level, ideology becomes an integral part of the human instinctive urge to plan, rationalize, and legitimize actions or behavior, whether as a self-aware protagonist of a major historical transformation or as an unconscious actor in a familiar domestic process of routine routines.

This understanding is in line with the phrase that complements Hamilton related to the definition of ideology which stipulates that ideology is intended to justify certain patterns of behavior of a person or group of people. Individuals or community groups tend to try to show, support, realize, prove or maintain a certain value by a person or group of people. This makes the idea of an ideology related to its function either intentional or unconscious or unconscious as a cultural construction (see Griffin, 2006). This is relevant in the context of the life of the Toraja ethnic community.

As a community that continues to keep its culture as an important part of various aspects of their daily life, the Toraja ethnic group keeps Adat as a behavior basic standard that believed to maintain their life. That is included in the political filed. This condition is an important background that marks the tendency of Toraja's political behavior in the 
regional election. The attitude tendency shows its clear manifestation when the election mechanism uses the direct election mechanism.

Basically, the regional election carried out through direct election methods are one of the efforts of the government of the Republic of Indonesia to provide change for local people actively and equally involve as democratic value. Therefore, democratic principles that put people equally in political rights and opportunities form the basis of thought formalized through law. Thus, the government hopes that people will behave in accordance with the formal legal guidelines. In the context of the existence of ideology, the election is placed on acceptance of the principles of more liberal democratic ideology. Since one of the most important principles under this ideology is the equality for everyone, the presence of the regional election in the toraja region should running under this principle. But due to the existence of Adat, the phenomenom seems creates fundamentally different condition. This is condition basically put the toraja ethnic group faced two basic guiding behaviors, the democracy values regulated by formal law and the Adat as their fundametal principle of life. This condition then forces the toraja people to emerge separate attitude as a reflection of the existence of two fundamental standard of behavior.

In the 2015 regional election, with claims to the Toraja region as sacred land as part of their adat existences, this region must be led the adat-appropriate leader. The leaders must be people who occupied four conditions taught by Adat. This condition makes the rule of law that allows everyone to have the opportunity to become a leader is not appropriate. It made the opportunities for non-aristocratic toraja people and as well as the non-toraja people become closed since beginning. Although at the beginning of the regional election process there were several names from non-nobles who were discourse to participate in the election, at the end the names were dissapear from the candidate list. It shows Adat influence the toraja people behaviours in the election.

For the non-Toraja that considers as "pendatang" or migrants who consist of around $20 \%$ of the total population in this region, basically they still have the opportunity to participate in the election contestation. At least they may be able to running for the regent's deputy position to represent the proportion of non-Toraja people. But in fact, since the reform era, it never happened. The migrants seem willingly accept themselves as migrants that has not rights to lead this land. It then makes them never attempt to challenge the political hegemony of the Adat in this region as the political fundamental aspect (sukri 2018). It made not only the Toraja ethnic group organization but also the modern political institution such as the political party influenced by Adat.

That fact from the regional election showed that political parties prefer to follow the adat guidelines in determining the appropriateness of their supported candidates. This is attributed to their understanding of the political behavior of the Toraja people who will vote based on adat appropriateness. Moreover, since the administrators of political parties are coming from the Toraja people, then They deeply understand which the most appropriate candidates that will be voted by the majority voters, the Toraja people. Therefore, they do not want to take the risk of ignoring Adat because it has implications for the level of electability in front of the Toraja people. This condition shows how modern political institutions such as political parties have to respect the Toraja 
fundamental values (Tamma, 2017). The influence turned out not only to the demands of the appropriateness of candidates based on Adat. Various processes in the effort to win the contestation were also influenced by the existence of Adat in the community. The requirement to get sympathy and support from the majority of the people makes the Candidates in the 2015 regional election in the Toraja region use more activities related to Adat.

It was based on the belief that various customary activities as adat implementation could provide opportunities for them to gain sympathy from local people. Therefore, the Candidates generally approach the community more through spaces that close to the adat requirements. In this case, several important events in the Toraja customary guidance related to the funeral ceremony "Rambu solo" or ceremonies related to happiness "Rambu tuka" are more widely used by the Candidates. Since during those events, many people gathered it also presented many important and influential traditional leaders, the events that might become a political event to socializing and to got support.

During the 2015 election process, the Candidates showed a tendency to better use this path because it was considered to be more able to bring them closer to the community while respecting adat guidelines (sukri, 2018). Thus, even though the competition between Candidates in the regional election is political competition, the existence of Adat as a standard of behavior for the Toraja ethnic group which is the majority voter makes the competition appear more in social-cultural spaces. It is mainly to ensure that the Candidates are still fix to the adat appropriateness. By looking at various facts that are shown from the behavior of the Toraja people, it shows the existence of customary domination in the process which seems ignored democratic values were as universally accepted by many people in the world. The phenomenon shows that in certain contexts a particular community of people can bring up a standard of behavior that is the basis of their ideology in addressing the conditions occurred in their region. This phenomenon shows that Toraja people prefer to use their local guidance even though it tends to conflict with the general tendency in Indonesian society that believes democracy and equality.

Furthermore, what was happened in the Toraja regional election shows the fact that Adat has succeeded in utilizing formal rules to provide identification of the existence of its basic values in Toraja ethnic behavior. For a long time, especially during the new order era, the influence of local values tends to be seen as something that only affects the nonformal domain through various social activities and traditional rituals. It turns out that the local election process as a formal domain under state regulation actually becomes a sphere that provides justification and affirmation of Adat fundamental influence where authorized by the formal state institutions. Thru the regional election, the Toraja actually perform how Adat used as defending factors to their existence. It seemed an important aspect to keep their existence sustainability. Adat is not just as daily life guidance but also contains various fundamental political standards that should be obeyed as part of the effort to keep the land will still suitable for their uniqueness context as people community as well as their land as the sacred land. 


\section{Conclusion}

Empirically Adat for the Toraja ethnic groups is important guidance to live in harmony and wealth, including in its socio-political environment. Therefore, when an outside thing came into their living systems such as democracy through the regional election as a mechanism for determining the leaders of formal government in their territory, it will face the adat existences. As trustfully believe system, Adat becomes standard for the Toraja ethnic group behavior where also fundamentally regulates the appropriateness concept of leader even for the formal institutions in their land. As their claim, the Toraja region, as their sacred land inherited by their ancestors, makes the regions must be maintained through the adat guidance, including in the regional election. It is important due to the involvement of Adat in the election actually as part of the ethnic group identity existence that unique to others. Adat is the fundamental standard for various behaviors of this ethnic group. It means the appropriateness attitude will be seen under this standard, including how to behave appropriately within the regional election.

The principle of the election is based on democratic values. It is respect to the equality of each individual were regulated through the formal law that should be respected by all people. However, for the Toraja's people, the event was not only the way to respect formal law but also to implement Adat as fundamental guidance. Moreover, as part of their fundamental existence as indigenous people, Adat should play a prominent role in influencing the result. Under these circumstances, the Toraja people have their values to ensure the leader's appropriateness. It made Adat actually play as the Toraja ethnic ideology in the political field.

In the end, a phenomenon from Toraja shows how Adat that was played as local ideology able to influence important the democracy event. Even it was regulated through formal law under the democracy standard ideology. However, for Toraja people it was only as part of the process under that were influence by the Adat as a prominent role. It showed when a local-values became local ideology that challenges democracy as an important ideology where so far dominates the mainframe of how people elect their leader in the modern state nowadays. It possibly due to the Toraja uniqueness existence with Adat as their local ideology and important part of their existence. It made even the Adat seems in the opposite position to democracy idea where seen not respect to the equality for all people, but it still seen as the propriate condition for the Toraja ethnic group where it accepted as an objective condition of their context.

\section{References}

Adams, K.M. (1997). Ethnic Tourism and the renegotiation of Tradition in Tana Toraja (Sulawesi, Indonesia). American Ethnologist, Vol.36, No.4. pp. 309-320, Autumn.

Alfred, T., Corntassel, J. (2005). Being Indigenous: Resurgences against Contemporary Colonialism. Journal Government and Opposition. pp. 597-614.

Ananta., Aris., Arifin, E.N., Hasbullah, M.S., Handayani, N.B., Pramono, A. (2014). Demography of Indonesia's Ethnicity. ISEAS-Yusof Ishak Institute.

Aspinall, E., Fealy, G. (2010). Soeharto's New Order and Its Legacy: Essays in honour of Harold Crouch. ANU Press.

Baruallo, F. (2010). Kebudayaan Toraja (Masa Lalu, Masa Kini dan Masa Mendatang). Universitas Atmajaya-Jakarta. 
Burns, P. (1989). The Myth of Adat. Journal of Legal Pluralism. Nr. 28. Pp 1-127.

Davidson, J.S. et.al (ed). (2010). Adat dalam Politik Indonesia. KITLV-Jakarta and Yayasan Pustaka Obor Indonesia.

Henley, D. (2008). In the name of Adat: regional perspectives on reform, tradition, and democracy in Indonesia, Modern Asian Studies 42, pp. 815-852.

De Jong, E. (2013). Making a Living Between Crises and Ceremonies in Tana Toraja: The Practice of Everyday Life of a South Sulawesi Highland Community in Indonesia. Brill, Leiden and Boston.

Eklöf, S. (1999). Indonesian Politics in Crisis: The Long Fall of Suharto 1996-98. Nordic Institute of Asian Studies (NIAS).

Emanuel, L. (1999). Latin for Lawyers. The Language of Law. J.D., Harvard Law School 1st Edition. Emanuel Publishing Corp. 328 Boston Post Road - Larchmont, NY.

Gold, J., Thorpe, R., Mumford, A. (eds). (2010). Handbook of Leadership and Management Development. Aldershot: Gower.

Griffin, R. (2006) Ideology and culture. Journal of Political Ideologies. 11:1. pp. 77-99.

Hamilton, M.B. (1987). The Elements of the Concept of Ideology. Political Studies, XXXV.pp. 18-38

Hooe, T.R. (2012). "Little kingdoms" (Adat and inequality in The island, Eastern Indonesia). PhD. Dissertation, University of Pittsburgh, USA.

Kombong, TH. et.al. (1992). Aluk, Adat dan Kebudayaan Toraja dalam Perjumpaannya dengan Injil. Pusbang-Badan pekerja Sinode gereja Toraja.

Lakin, K. (2005). Legal Pluralism in Archaic Greece. December. Stanford Department of Classics \& Stanford Law School. (unpublished paper).

Lay, C. (2012). Democratic Transition in Local Indonesia: An Overview of Ten Years Democracy. Jurnal Ilmu Sosial dan Ilmu Politik. Volume 15, Nomor 3, Maret. Pp. 207-219.

Li, T,M. (2000). Articulating Indigenous Identity in Indonesia: Resource Politics and the Tribal Slot. Society for Comparative Study of Society and History. 00104175/00/1796-0103.9.50, pp. 149-179.

Liddle, R.W. (1995). Soeharto's Indonesia: Personal Rule and Political Institutions. Pacific Affairs. Vol. 58, No. 1 (Spring). pp. 68-90

Lombard, D. (2005). Nusa Jawa Silang Budaya. Gramedia Pustaka Utama. Jakarta.

Raišienè, A.G. (2014). Leadership and Managerial Competencies in A Contemporary Organization From Standpoint og Bussiness Executives. Economics \& Sociology, Vol. 7, No 3. pp. 179-193.

Simblon, P.T. (2007). Menjadi Indonesia. Penerbit Buku Kompas. Jakarta.

Sukri, S. (2016). Democracy and Revivalism of Ethnic Group Identity In the Indonesian Regional Election after Suharto. (Paper) Was Presented at the 24th WorldCongress of Political Science. Poland. (paperroom.ipsa.org/papers/paper_53057.pdf).

Sukri., (2018). The Toraja as an Ethnic Group and Indonesian Democratization Since the Reform Era. (Dissertation) Bonn University, Germany.

Tamma, S. (2018). Pemilihan Kepala Daerah dan eksistensi Komunitas MAsyarakat Adat Toraja. Jurnal Review politik. Vol 7 No. 2 Desember.

Turpel, M.E. (1992). Indigenous Peoples' Rights of Political Participation and SelfDetermination: Recent International Legal Developments and the Continuing Struggle for Recognition. Cornell International Law Journal Vol.5 pp.5879-602.

Twining, W. (2010). Normative and Legal Pluralism: A Global Perspective Normative and Legal Pluralism. Duke Journal of Comparative E International Law. Vol 20. Pp. 473-517.

Tyson, A.D. (2010). Decentralization and Adat Revivalism in Indonesia; The Politics of Becoming Indigeneous. Routledge New York. 
United Nations. (1997). The Rights of Indigenous Peoples. United Nations, Fact Sheet No.9 (Rev.1).

Waldron, J. (2002). "Indigeneity? First Peoples and Last Occupancy". Victoria University of Wellington, Law School Forthcoming. Journal of Public Law. Vol. 1, pp.1-57.

Waterson, R. (2009). Paths and Rivers; Sa'dan Toraja Society in Transformation. KITLV, Leiden.

Yunus, R., Tamma, S. (2014). Importance of Cultural Legitimacy to the Local Government in Indonesian Democracy. International Journal of Administrative Science and Organization. Volume 21. Number 1. Pp. 27-34.

Szalay, L.B., Rita M.K. (1972). Its Meaning and Measurement. Comparative Political Studies. pp. 151-173. 